MAYER PÉTER

\title{
Megjegyzések Sapphó Kypris-költeményének rekonstrukciójához és értelmezéséhez (5-6skk.)
}

\begin{abstract}
A tanulmány számba veszi a Sapphó Kypris-költeménye 5-6. sorára vonatkozó lehetséges rekonstrukciókat, és kritikailag elemzi, valamint értelmezi ezeket a sapphói életmú és a korai görög líra tágabb összefüggésében. ${ }^{1}$
\end{abstract}

Kulcsszavak: Sapphó, Kypris-vers, Erós, papirusz, szövegkritika, gender

Sapphó 2014-ben publikált Kypris-verse, ${ }^{2}$ amely a szakirodalomban bevett elnevezését címzettje, Aphrodité költeménybeli megszólításáról kapta, rövidsége ellenére több szempontból is izgalmas újdonságot jelent az ismert költői életmüben.

A sapphói strófákból álló szövegből két, meglehetősen bizonytalanul rekonstruálható versszakot, valamint egy néhányszavas mondatot ismerünk, emellett pár szót, illetve szótöredéket. Az első versszak eddig napvilágot látott olvasatai még a szöveg gondolatmenetét is jelentős eltérésekkel rekonstruálják, ezért inkább csupán exempli gratia álljon itt az

\footnotetext{
${ }^{1}$ A publikáció az MTA-SZTE Antikvitás és Reneszánsz: Források és Recepció Kutatócsoport (TK2016-126) támogatásával jelent meg.

${ }^{2}$ Editio princeps: OBBINK (2014), vö. még OBBINK (2016). A szövegre vonatkozó szakirodalom a 2014-es Sapphó-papiruszok jelentőségének és az általuk keltett széles körű - a szakmabeliek szűkebb csoportján messze túlterjedő - figyelemnek köszönhetően meglepően bőséges. Alapvető tanulmánygyüjtemény a tárgyban: BIERL-LARDINOIS (2016). A Kypris-költemény rekonstrukciója és értelmezése szempontjából fordulatértékű volt Simon BURRIS (2017) felfedezése, aki újabb papirusztöredéket azonosított a szöveg forrásaként, ezzel lehetővé téve épp az itt tárgyalt második versszak teljesebb megismerését, és számos korábbi szövegrekonstrukció meghaladását.
} 
editor princeps, Dirk Obbink legújabb szöveghelyreállítása a vers elejére vonatkozóan:

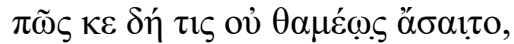

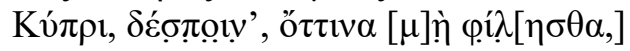

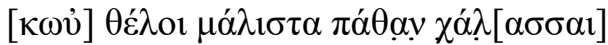

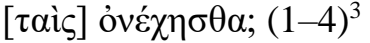

„hogy ne gyötrődne gyakorta az, Kypris úrnő, akit [ne]m kedv[elsz], [s hogy ne] akarna a lehető leginkább szab[adulni] a szenvedéstől, [aminek] kiteszed öt?"

Ha az említett véleménykülönbségek dacára megkísérelnénk legalább a gondolatmenet tekintetében többé-kevésbé közös nevezőre hozni a különböző szövegolvasatokat, a következőképpen foglalhatnánk össze az első versszak tartalmát: „hogy ne gyötrődne az, akit Aphrodité kitüntet (akár kedvezö, akár büntető) figyelmével, miközben szenvedését vagy szenvedélyét megpróbálja legyürni/rejtegetni?". A címzett, Aphrodité megszólításával implicit módon megjelenik a költői persona, majd a második versszakban immár explicit utalás - az „engem” személyes névmás (5) - formájában is, a beszélő tehát személyes érintettje a versbeli ima tartalmának.

A költemény második versszaka egy figyelemre méltó költői képpel indul. A beszélő azt rója fel - minden bizonnyal - Aphroditének, hogy

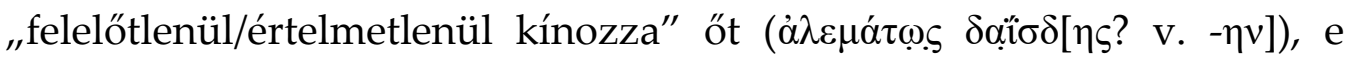
kínzás kapcsán pedig az eddigi olvasatok több potenciális, s a gyötrődés képzetével összefüggésben magyarázatot igénylő motívumot vélnek azonosítani (5-6skk.). A továbbiakban ennek az utóéleti szempontból is izgalmas mondatnak kísérlek meg utánajárni, néhány megjegyzéssel támogatva meg a szöveg rekonstrukcióját és tágabb összefüggésben való értelmezését.

Csak a teljesség kedvéért érdemel említést $K$. Tsantsanoglou és $S$. Tselikas közösen kidolgozott, kevéssé meggyőző szövegrekonstrukciója: ${ }^{4}$

$\left.\mu \mu^{\prime}\right]$ ỏvé $\chi \eta c \theta \alpha$.

\footnotetext{
${ }^{3}$ OBBINK (2020: 232), építve mások javaslataira is.

4 TSANTSANOGLOU (2019).
} 


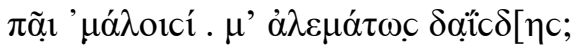

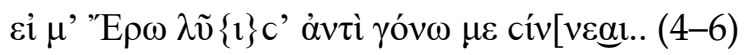

A szerző angol nyelvű fordításában: „Don't hold me back. Why do you tear me to pieces with tender ones in vain? Come now! Set me free from Eros. You are hurting me in order to please your son."

A szöveg ilyetén helyreállítása tartalmukban olykor kifejezetten banálisnak ható, emellett Sapphó ismert szövegeivel nehezen összeegyeztethetően rövid mondatokkal számol (például néggyel mindössze két és fél sorban!), ami furcsán szaggatott beszédmódot eredményezne, valamint meggyőző párhuzamokkal alá nem támasztható szóalakok használatát feltételezi. ${ }^{5}$

Jóval meggyőzőbb tanulmányában Giambattista D’Alessio a mondatot még az előző versszak végétől indítja és az 5. sort így állítja helyre:

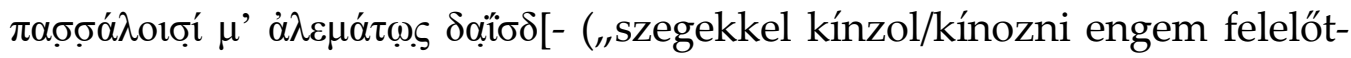
lenül"). ${ }^{6}$ A kutató versszakhatáron átnyúló mondatot (enjambement) feltételez - szemben valamennyi, a szöveget illető aktuális ismereteinkkel összhangban levő rekonstrukcióval, amelyek mind $\pi \tilde{\alpha} 1$ „miért?” mondatkezdő kérdőszót vélnek azonosítani a 2. versszak kezdősorában (5) -, s e feltételezés erős paleográfiai támaszt kap azon körülménynek köszönhetően, hogy ugyanezen papiruszlapon az előző költemény enjambement nélküli versszakzárlatait minden esetben egy jól kivehető pont jelöli, míg e helyütt a pont egyértelmúen hiányzik. ${ }^{7}$ E kétségkívül erős paleográfiai érvet ugyanakkor egy hasonlóképp erős nyelvi-stilisztikai érv ellensúlyozza: a 6. sorban nagy bizonyossággal olvasható i $\mu \varepsilon ́ p \omega\langle 1\rangle$ dativus instrumenti ugyanebben a mondatban zavaró párhuzamosságot és esettani azonosságot jelentene a $\pi \alpha \sigma \sigma \alpha ́ \lambda o \imath \sigma r$ eszközhatározóval: „felelőtlenül/értelmetlenül kínzol (vagy: kínozni?) engem szegekkel - vággyal"? ${ }^{8}$ A kép jobb megértéséhez szükséges tudni, hogy $\delta \alpha i \zeta \zeta \omega$ a korai görögben, így pl. Homérosnál, egyfelől „,kettévág”-ot, „,szétvág”-ot jelent, ez „elpusztít” jelen-

\footnotetext{
${ }^{5}$ Jó példa mindháromra a 6. sor olvasata, ahol a beszélő felszólítja az istennőt, hogy szabadítsa meg őt tulajdon fiától (!), éppen attól az Eróstól, akinek érdekében (!) maga az istennő a költőnőt gyötri. A rekonstrukció kritikájához ld. még NERI (2017: 14).

${ }^{6}$ D'Alessio (2017).

${ }^{7}$ D'Alessio (2019: 30-31).

8 Vö. OBBINK (2020: 228, 17. jz).
} 
téssé is általánosult, s emellett a szó - passzív alakok formájában pszichológiai értelemben (lélekre, szívre vonatkozóan) „kínlódik” jelentéssel is bír. ${ }^{9}$ A szögekkel történő gyötrés említése tulajdonképpen a test szögekkel történő szétfeszítését, egyfajta keresztre feszítést - tehát: kínzást, avagy főbenjáró büntetést - evokálhatott Sapphó hallgatóiban és olvasóiban, ami figyelemre méltóan korai előzménye lenne a római irodalomban azután bevett motívumnak az extrém szerelmi szenvedés érzékeltetésére (vö. locus classicusként Catull. 85 fieri sentio et excrucior mondatát). ${ }^{10}$ D'Alessio szerint Sapphó e helye lenne a legkorábbi példa e képzetre a görög irodalomban, ez azonban - amennyiben a formális kínzás és büntetés motívumára gondolunk - legalábbis árnyalásra, avagy amennyiben általában az átdöfés extrém fizikai kínjáról beszélünk - helyesbítésre szorul. A Kr. e. 7. századi Archilochos egy iambosában így fogalmaz: „szerencsétlenül küszködöm a vággyal, élettelenül, csontjai-

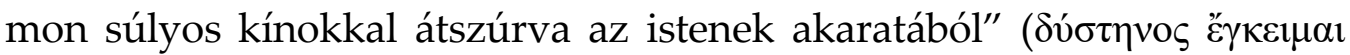

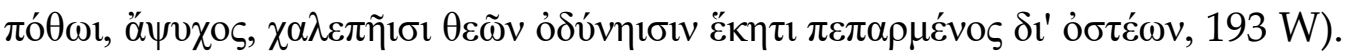
A nyilatkozat pontos értelmét némiképp elhomályosítja a metonímikus átdöfés ugyancsak metaforikus eszközének helyettesítése a denotatív „kín, fájdalom” kifejezéssel, ám a mondat motívumkészlete így is összeegyeztethető mind a keresztre feszítés képzetével, mind a harcmező világával, ${ }^{11}$ amely utóbbiban a fizikai kín, a csonton is átható sérülés forrása nyilvánvalóan a nyíl vagy a dárda. Ebben az esetben gender-szempontból izgalmas és a férfi és női szemszögből megélt szerelmi vágy különbözőségére nézve sokatmondó lenne a különbség Sapphó büntetés- és kínzásmotívuma - amely természetes módon a tehetetlenség és kiszolgáltatottság élményén alapul -, valamint Archilochos férfiköltészetének sebesült harcos motívuma között, amely a férfi beszélőt mégis csak aktív, autonóm és - elvben - eséllyel harcba vonuló cselekvőként festi le a szerelem csa-

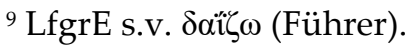

${ }^{10}$ D'Alessio (2017: 26).

${ }^{11}$ Utóbbi eshetőséghez ld. SWIFT (2019: 360-361). A kommentárszerző hivatkozik egy

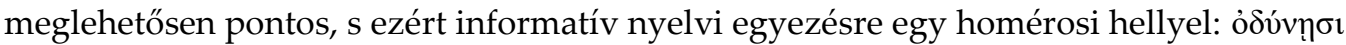
$\pi \varepsilon \pi \alpha \rho \mu \varepsilon ́ v o \varsigma$ („,kínoktól átjárva/átszúrva”; Hom. Il. 5, 399), ahol Hádést Héraklés nyílvesszeje járja át.
} 
tamezején, még ha alul is marad aktuálisan az istenek akaratával szemben.

J. Hammerstaedt az ostromló tengerár, hullámzás említését véli kiolvasni a szövegleletből a szerelmi szenvedés kapcsán, amely a mondat egyéb részeire vonatkozó jelenlegi ismereteink szerint így hangozna: $\pi$ ậı

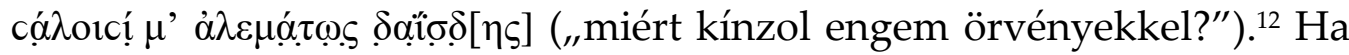
ez a javaslat helytálló, a fizikai fájdalomként, kínzásként vizionált szerelmi gyötrelem képét a tengervíz mozgásának képzete egészítené ki, s e megközelítésben a szerelmi vágy nem csupán kegyetlen ellenségként ejt sebet az emberen, hanem elemi erőként ítéli hullámai hátán tehetetlen vergődésre a beszélőt. Ezen elmélet ellen is szól azonban a fent említett probléma, hogy cádoicı és i $\mu \varepsilon ́ \rho \omega\langle\imath\rangle$ esetében is olyan párhuzamos kifejezéseket kellene feltételeznünk, amelyek egymás mellett inkább zavarólag hatnának.

Nem áll meg viszont ez utóbbi kritika Simon Burris olvasatával szemben, amely mára támogatói között tudhatja mások mellett a szöveg közreadóját is:

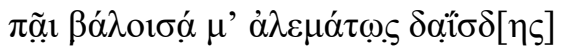

$\varepsilon \dot{\imath} \mu \varepsilon \dot{\varepsilon} \rho \omega\langle\imath\rangle \lambda v \dot{\sigma} \sigma \alpha \nu \tau \imath(5-6)^{13}$

„Mi végre lősz rám, és szúrsz át veszettül őrjöngő vággyal értelmetlenül?"

Azt a lényegi kérdést, hogy a $\beta \alpha ́ \lambda$ orcó olvasat a szóvégi $\alpha$ miatt paleográfiailag meggyőző, avagy egyáltalán lehetséges-e, a kutatók eltérően ítélik meg, de jelenlegi ismereteink alapján nincs okunk elvetni e szövegváltozat lehetőségét. ${ }^{14} \mathrm{~A}$ nyíllövés és az eredetileg késsel való vágást

12 OBвiNK (2014: 48) az editio princepsben még maga is támogatta ezt az olvasatot. Ugyancsak có $\lambda$ oicí-t olvas FERRARI (2014: 13-14), és NERI (2017: 14) is számol ezzel a lehetőséggel.

${ }^{13}$ BURRIS (2017: 13); ugyanígy BENELLI (2017), LARDiNOIS (2018: 4, 30. jz) és legutóbb OBBINK (2020: 232).

${ }^{14}$ A kérdés jelentőségét az adja, hogy amennyiben oıc után csak egy keskeny betü, az ióta számára van elég hely a papiruszon a következő szó $\mu$-je előtt, úgy có̀ orcí-t vagy egyéb dativusos határozókat kell feltételeznünk, amely - mint láttuk - szintaktikailag nehézkes, és igencsak körülményessé teszi a szöveg fordítását. BURRIS (2017: 12) egy, a 
jelentő $\delta$ aǐ $\omega$ ige egy szerkezetbe helyezése furcsának hathat, de az ige általánosabb jelentései („pusztít”, "gyötör") fényében nem kizárható, és

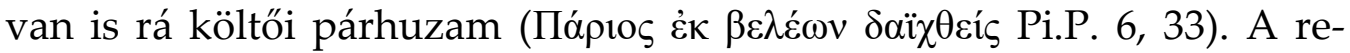
konstrukció nagy újdonsága, hogy Sapphó e sorait az egyetlen példaként mutatná az ismert archaikus és klasszikus kori görög irodalomból arra, hogy Aphrodité, s nem Erós az, aki nyilával szerelmet ébreszt valakiben. ${ }^{15}$ Még messzebb vezető érdekessége a szöveg ilyetén történő helyreállításának az a tény, hogy Sapphó és Aphrodité ezen és más versekből mozaikszerűen kirajzolódó viszonyának, s ezáltal magának a sapphói szerelem-élménynek markánsan új vonását villantaná fel. A sapphói versek beszélője tudvalevőleg hangsúllyal beszél erósi kihívásainak kínjairól, vagy a szerelem leigázó, akár sokkoló hatásáról. Vegyünk csupán néhány jellemző példát. A szerelmes valósággal „őrült lelkű”

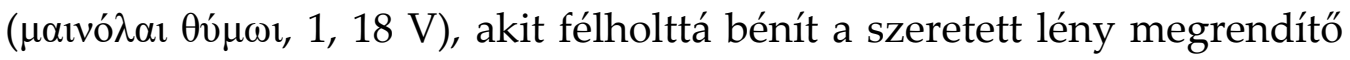
látványa (31 V). Erós egy „keserédes, lehetetlen (avagy: legyürhetetlen) lény" (130 V), aki úgy hat a költő szívére, mint a hegyi tölgyerdőre lecsapó orkán $(47 \mathrm{~V})$. Sőt egy helyütt alighanem szintén a szerelemre utal, amikor egy levegővétellel mond le a méz örömeiről és a méh fullánkjáról (146 V). ${ }^{16}$ A sapphói szerelem- és Aphrodité-képnek ugyanakkor legalább ilyen hangsúlyos vonása a költő és az istennő meghitt, szövetségesi viszonya (vö. locus classicusként a költőnő szavai az istennőhöz:

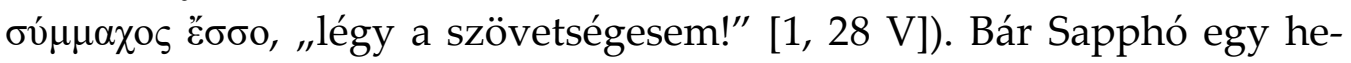
lyütt nem hallgatja el például, hogy az istennő szerelmi ügyben megrótta öt valamiért ( $\dot{\varepsilon} \mu \varepsilon \dot{\varepsilon} \mu \varphi[\varepsilon \tau$ ', 22, $15 \mathrm{~V})$, a Kypris-vers ebben az olvasatban

papiruszon végigfutó, javító célú ragasztásra és a laprészek emiatti részleges átfedésére hivatkozva feltételez elegendő helyet a szóvégi $\alpha$ számára a most látható, elégtelen szóközméret dacára. Bár TSANTSANOGLOU (2019: 75) ezt illető cáfolata - legalábbis az egyetlen, viszonylag jó minőségben és nagyításban publikált fénykép alapján (ld. BURRIS [2017]) - meggyőzőnek tünik (ugyanígy értékel NERI [2017: 14]), a papiruszt behatóan ismerő OBBINK (2020: 228, 17. jz) megvédi BURRIS olvasatát TSANTSANOGLOU cáfolatával szemben. Mindezekre tekintettel módszertanilag jelen helyzetben helyesnek tünik valós és meggyőző lehetőségként számolnunk BURRIS ßọ́iorcọ́ javaslatával.

15 OBBINK (2020: 230sk.), Aphrodité egyáltalán nem harcias természete kapcsán utalva az Ilias híres jelenetére, amikor a halandó Diomédés által megsebzett istennő fájdalomtól gyötörten távozik a csatatérről az Olymposra (Hom. Il. 5, 311-370).

${ }^{16}$ Ez Martin L. WEST (2014: 11) szellemes és meggyőző értelmezése a töredékről. 
szintet lépne a költő és az istennő konfliktusát illetően: kifejezetten ellenségesnek és agresszívnek mutatná be Aphroditét Sapphóval szemben, s ezzel - közvetve - a szerelem képzetét is jóval negatívabb, embert próbálóbb, sőt pusztítóbb mivoltában ragadná meg az eddig ismert költői nyilatkozatokhoz képest.

Tanulságos e szempontból a mondatban említett „vágy” jelzője. Obbink az editio princepsben ${ }^{17}$ (és őt követve mások) $\lambda v ́\{1\}$ cavț yóv’ (,térdet megoldó", az ugyancsak sapphói $\lambda v c \mu \varepsilon \dot{\lambda}\rceil c$ "tagokat oldó" [130, 1 V]

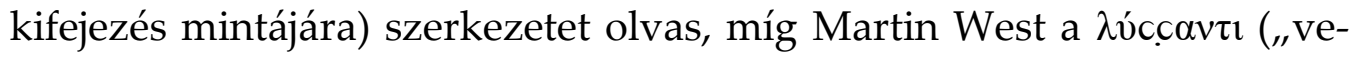
szettül ôrjöngö") rekonstrukciót javasolta, ${ }^{18}$ amit később Burris és őt követve legutóbb maga Obbink is elfogad. ${ }^{19}$ A két lehetőség mérlegelésénél is érdemes kitekinteni a sapphói és a még tágabb költészeti korpusz tanulságaira, s nézetem szerint célszerü e kérdést is gender szerinti elkülönítésben vizsgálnunk. West saját olvasatát alátámasztandó találóan

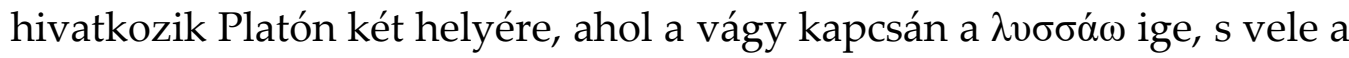
veszett őrjöngés képe kap említést. ${ }^{20}$ Platón azonban Sókratés kapcsán a férfivágyról beszél, arról, aminek robbanásveszélyes elegye a sympotikus borélvezettel Anakreón ismert vallomásait hívta életre a benne tomboló, olykor akár hallucináló szerelmi vágyról (vö. pl. PMG 356; 359; 376; 396; 398; 428). Veszettség és vágy együttes említése a szerelmi őrület ( $\mu \alpha v i ́ \alpha)$ extrovertált, őrjöngő, már-már agresszív formáját idézi fel (vö. Anakr. PMG 398: „Erós játékkockái pedig: őrjöngés és csetepaté”), ami valójában nem jellemzője a sapphói szerelem világának. ${ }^{21}$ A költőnő egyrészt a vágy kapcsán meglepő módon nemigen beszél őrületről - a már

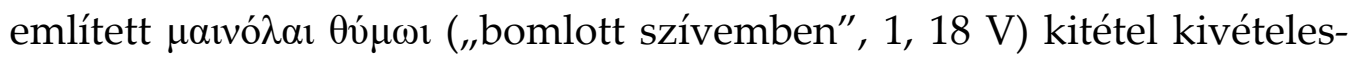
nek számít a szövegkorpuszban -, másfelől a sapphói persona szerelemélményének közismert alapvonása a kiszolgáltatottság és a tehetetlen-

\footnotetext{
17 OBBINK (2014: 49).

18 WEST (2014: 11).

19 BURRIS (2017: 13), OBBINK (2020: 229). A két olvasat dilemmája kapcsán BuRRIS (2017:

12) érve, TSANTSANOGLOU (2018: 75-76) cáfolata, és saját meglátásom ugyanaz, mint fent ßá̉otcó esetén (vö. 14. lábjegyzet).

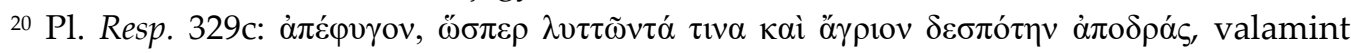
586c: "̋́ $\rho \tau \alpha \varsigma . . . \lambda v \tau \tau \tilde{\omega} v \tau \alpha \varsigma$.

${ }^{21}$ Aliter OBBINK (2020: 228): „Sappho thus characterizes herself as raging uncontrollab-

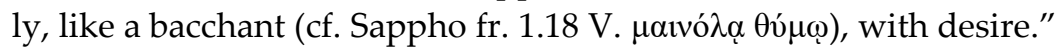


ség, amelyben az eszét vesztett szerelmes legfeljebb a csendes őrület állapotában leledzhet a már említett 31. töredék vágy okozta testi szimptómáinak pszichológiai megfelelőjeként, egyfajta mentális paralízisként. Ha a két olvasat között pusztán tartalmi-stilisztikai alapon kellene választanunk - márpedig paleográfiai alapon a kérdés jelenleg nem eldönthetö -, úgy az elmondottak fényében a $\lambda v ́\{1\}$ cavț yóy” („,térdet megoldó") valószínübbnek mondható. Amennyiben pedig egy későbbi leletnek köszönhetően kiderülne, hogy Sapphó itt veszett őrjöngéshez hasonlítja a benne lobogó vágyat, úgy a Kypris-vers egy további ponton szolgálna izgalmas újdonsággal a sapphói életmű ismerői számára.

\section{Felhasznált irodalom}

BENELLI 2017

L. BENELLI, Tra 'vecchia' e 'nuovissima' Saffo. Riflessioni sul testo, 2017. https://www.academia.edu/32456485/L_Benelli_Tra_vecchia_e_ nuovissima_Saffo_Riflessoni_sul_testo_Salamanca_5_04_2017, Utolsó megtekintés: 2021. 10. 10.

BIERL-LARDINOIS 2016 A. BIERL - A. LARDINOIS (eds.), The newest Sappho (P. Sapph. Obbink and P. GC inv. 105, frs. 1-4), Mnemosyne, Supplements vol. 392, Leiden - Boston, 2016.

BURRIS 2017

S. P. BURRIS, A New Join for Sappho's 'Kypris Poem': P.GC inv. 105 fr. 4 and P.Sappho. Obbink, Zeitschrift für Papyrologie und Epigraphik 201 (2017), 12-14.

D'Alessio 2017 G. D'Alessio, Aphrodite's Torture: Sappho, 'Kypris Poem' v. 5., Zeitschrift Für Papyrologie Und Epigraphik 203 (2017), 25-26.

D'Alessio 2019 G. D'Alessio, Textual Notes on the 'Newest' Sappho (on Sappho, Fragments 5, 9, 17 V., and the Kypris Poem), Zeitschrift für Papyrologie und Epigraphik 211 (2019), 18-31.

FERRARI 2014

F. FERRARI, Saffo e i suoi fratelli e altri brani del primo libro, Zeitschrift für Papyrologie und Epigraphik 192 (2014), 1-19.

LARDINOIS 2018 A. LARDINOIS, Sufferings which Aphrodite sustains: A New Reconstruction of the First Strophe of Sappho's Kypris Poem, Zeitschrift für Papyrologie und Epigraphik 205 (2018), 1-5.

NERI 2017

C. NERI, Afrodite violenta (Sapph. fr. $26=$ 'Kypris Poem'), Eikasmos 28 (2017), 9-21.

OBBINK 2014

D. OBbinK, Two New Poems by Sappho, Zeitschrift für Papyrologie und Epigraphik 189 (2014), 32-49.

OBBINK 2016

D. OBBINK, The Newest Sappho: Text, Apparatus Criticus, and Translation, in: A. Bierl - A. Lardinois (eds.), The newest Sappho (P. Sapph. Obbink and P. GC inv. 105, frs. 1-4), Leiden - Boston, 2016, 13-33. 
OBBINK 2020

D. OBBinK, Kypri Despoina: Sappho's 'Kypris Poem' Reconsidered, in: P. Burian - J. S. Clay - G. Davis (eds.), Euphrosyne: Studies in Ancient Philosophy, History, and Literature, Berlin - Boston, 2020, 223-235.

SWIFT 2019 L. SWIFT (ed., transl.), Archilochus: the Poems. Introduction, Text, Translation, and Commentary, Oxford, 2019.

TSANTSANOGLOU 2019 K. TSAntSAnOGLOU, P. Sapph. Obbink: the 'Kypris Poem', in: Studies in Sappho and Alcaeus, Berlin - Boston, 2019, 72-85.

WEST 2014 M. L. WeST, Nine Poems of Sappho, Zeitschrift für Papyrologie und Epigraphik 191 (2014), 1-12.

\section{Sappho, Kypris Poem vv. 5-6: Some critical and interpretive re- marks}

The article surveys possible restorations of vo. 5-6 of the Kypris Poem by Sappho, and critically evaluates them in the context of the poetic auvre and in syncrisis with other early Greek lyric statements about desire.

Keywords: Sappho, Kypris Poem, Eros, papyrus, textual criticism, gender 